Vol. (9), No. (32), Part Two, September 2019, PP. 1 - 41

\title{
Strategies for Teaching Primary
}

\section{school Students with Learning Difficiculties;}

\section{Dyslexia and Dyscalculia}

\author{
By \\ Rafif Alamro \\ Master of Inclusive Education \\ The Queensland University of \\ Technology (QUT) \\ Brisbane , Australia
}

DOI: $10.12816 / 0054853$ 


\title{
Strategies for Teaching Primary School Students with Learning Difficulties; Dyslexia and Dyscalculia
}

\author{
By
}

Rafif Alamro(*)

\section{Abstract}

Research continues to confirm that we can teach students with learning difficulties how to learn successfully by providing them with useful learning strategies. This research paper has been designed to investigate some of the most effective strategies for teaching primary school students with the learning difficulties dyslexia and dyscalculia. Identifying and effectively diagnose learning problems in students with dyslexia and dyscalculia can benefit both the students and the teacher. Thus, to inform the development of successful strategies and educational interventions, teachers should continually increase their knowledge of the information in the field of dyslexia and dyscalculia. Teachers and administrators addressing the educational needs of students with learning difficulties may benefit from this research. Parents may also find this research useful. The research opens by giving an overview of the importance of strategies for teaching students with dyslexia and dyscalculia, and an explanation of learning difficulties and the ratios of dyslexia and dyscalculia in primary school students. This is emphasises the needs for appropriate teaching strategies, to help these students succeed in their learning. Also, this research discussed the current evidence for teaching strategies to support students with dyslexia and dyscalculia, to insure teachers how these difficulties can be reduced. Students with LDs such as dyslexia and dyscalculia have the right to effective education which commensurate with their abilities and lead them to success. 


$$
\text { الملخـص العـربــي }
$$

تستمر الأبحاث في التأكيد على أنه يمكننا تعليم الطلاب الذين يعانون من صعوبات في

التعلم كيفية التعلم بنجاح من خلال تزويدهم باستراتيجيات تعلم مفيدة. تم تصميم هذه الورقة البحثية للتحقيق في بعض الاستراتيجيات الأكثر فاعلية لتعليم طلاب المدارس الابتدائية من ذوي صعوبات التعلم الذين يعانون من عسر القراءة وعسر الحسـاب. إن التعرف على مشـاكل التعلم وتشخيصـها بشكل فعـال لدى الطـلاب الذين يعانون من عسر القراءة وعسر الحسـاب يمكن أن يفيد الطـلاب والمعلمين على حد سواء. وبالتالي ، ذلك قد يساهم في تطوير الاستراتيجيات الناجحة والتدخلات التعليمية. أيضـا، يجب على المعلمين زيادة معرفتهم باستمرار للمعلومات في مجال عسر القراءة وعسر الحسـاب. يمكن للمدرسين والإدارينين الذين يعـالجون الاحتياجـات التعليميـة للطـلاب الذين يعانون من صعوبات في التعلم أن يستفيدوا من هذا البحث. قد يجد الآباء أيضًا هذا البحث مغيدًا. يبدأ البحث من خلال تقديم لمحة عامة عن أهمية استراتيجيات تدريس الطلاب الذين يعانون من عسر القراءة وعسر الحسـاب، وتقسـير صـوبات التعلم ونسـب عسر القراءة وعسر الحسـاب في طلاب المدارس الابتدائية. هذا يؤكد على الحاجة إلى استراتيجيات التدريس المناسبة ، لمسـاعدة هؤلاء الطـلاب على النجاح في تعلمهـ. كمـا ناقش هذا البحث الدليل الحسالي على استراتيجيات التدريس لدعم الطلاب الذين يعانون من عسر القراءة وعسر الحساب ، لضمان حصول المعلمين على هذه الصعوبات. يتمتع الطلاب من ذوي صعوبات التعلم، مثل عسر القراءة وعسر الحساب، بالحق في التعليم الفعال الذي يتتاسب مع قدراتهم ويقودهم إلى النجاح. 


\section{Introduction}

Teaching strategies play an important role in the success of the educational process when teaching students, in particular when teaching students with learning difficulties (LDs) such as dyslexia and dyscalculia at primary school level. For many years, attention has been focussed on this issue since many LDs are often exacerbated and caused by inappropriate teaching strategies. As a result of disappointing standards achieved by a high number of students in the last few years, there have been requests in several countries for schools to arrange teaching strategies that have been carefully evaluated for their effectiveness, rather than those based on teachers' own preferences, styles and intuition (Westwood, 2008). Learning difficulties (LDs) refer to a variety of conditions that might affect the acquisition, retention, organisation, understanding and use of nonverbal and verbal language. These confusions may impact learning in students who otherwise show at average abilities essential for thinking and reasoning. Furthermore, LDs result of impairments in one or more processes related to remembering, perceiving, thinking and learning (Clarke, Embury, Jones \& Yssel, 2014). The American National Center for Learning Disabilities (2011) identifies as the largest disability category, accounting for almost half (44.6\%) of all students aged 6 to 21 years. Students with LDs are considered to be the most rapid and largest expanding population of students (Burgstahler \& Moore, 2009; Chew, Jensen, \& Rosen, 2009; Foley 2006; Garrison-Wade \& Lehmann, 2009; Thomas, 2000) The term "learning difficulties" is a broad one and covers many different problems that students can face whilst undertaking their learning. 
As a result of the importance of teachers understanding the characteristics of students with LDs, and how to provide them with effective strategies, this research paper aims to provide teachers in the primary school context with effective strategies for teaching students with LDs, specifically the learning difficulties dyslexia and dyscalculia. This research will also provide an explanation about the current understanding of and the origins and core difficulties related to dyslexia and dyscalculia and the synthesis between them in order to inform the development of successful strategies and educational interventions for students with dyslexia and dyscalculia.

\section{Students with Learning Difficulties}

Understanding students with LDs and their learning is an important for teachers to understand how to provide a positive learning environment. This section will review LDs, specifically dyslexia and dyscalculia, and how teachers can understand these difficulties. In the past twenty years, students who are experience problems in learning have been given a variety of designations, such as, educationally subnormal, dull, at risk, low achievers. The hard-to-teach, slow learners and learning disabled. After a period of time each another this is often as a result of attracts its denial replaces designation. However, most countries applied the term learning difficulties to students who may facing difficulties in achieving adequate progress in the school curriculum, especially in basic skill areas including language difficulty, literacy and numeracy. In addition, students with LDs might face a problem that associated with just one specific school subject, or might be towards all subjects in its academic curriculum (Westwood, 2004). Learning difficulties (LDs) are often misunderstood, even though many students experience them. A teacher's lack of knowledge and understanding about LDs can lead to poor care for these students (Barber, 2011).

\section{4}


LDs occur when students are able to perform well in some contexts of learning but unexpectedly have issues with other contexts. These students typically need additional assistance to achieve successful learning in the classroom. LDs might be mild, moderate or severe, and students with LDs comprise a diverse group of individuals, exhibiting difficulties in various areas (Wong \& Butler, 2012). According to Bowe (2005), some students can learn to adjust and cope with LDs well while others may struggle throughout their study.

LDs often begins in childhood and is a lifelong condition. There are a wide variety of general learning characteristics associated with students with LDs, for example difficulties with basic skills such as reading and writing dyslexia - and mathematics - dyscalculia. These students have difficulty following directions and instructions to complete tasks and might also have poor fine-motor skills, which can affect the legibility of their handwriting, create difficulty in pronouncing words or reading multisyllabic words, with limited words and vocabulary knowledge in comparison to other students. Also, due to memory problems, students with LDs can display poor information retrieval (Hong \& Chick, 2013). In addition, research has shown that dyslexia often impacts $5-10 \%$ of the population, with estimates as $17 \%$. Some students may have mild forms, whilst for others it is more severe. Furthermore, dyslexia is considered one of the most common reasons behind reading difficulties in primary school students (Samuelsson \& Lundberg, 2003). In relation to dyscalculia and its percentage in primary school context, the research showed that approximately $3 \%$ to $6 \%$ of students suffer from dyscalculia and often have significant problems with mathematics (Butterworth, 2010). According to Reid and Lienemann (2013), the treatment of LDs students begins once the issue is discovered and identified. 
Therefore, success or failure depends on the attitudes of teachers' educational programs, a teachers' efficiency, and the support LDs students receive. There is no doubting the importance of understanding students with LDs and their problems is essential for teachers. However, there are many obstacles that might stand in the way of teachers when teaching these students. According to Busch, Pederson, Espin and Weissenburger (2001), teachers of students with LDs are often faced with multiple challenges. Also, their primary responsibility is to educate students with academic delays, other elements may play a role in determining their vocational efforts and their views about it as successful or unsuccessful. These obstacles are apparent in, service-delivery issues, school climate, student's characteristics, support systems, paperwork requirements, teacher's preparation, role ambiguity, administrative support and student's behavioural difficulties. As a result, this may affect the resulting efficacy of the teaching program, perceptions of teachers and their overall teaching strategies for LDs students.

\section{Gurrent Understanding of Dyslexia}

Dyslexia is a broad matter, and a large amount of research on it has been conducted; yet studies are ongoing, seeking increased and more detailed knowledge. In order to cover the most important information regarding dyslexia, this section will address the importance of understanding the arguments around dyslexia, the definition of the condition, the meaning of the word dyslexia and the kind of difficulties that can result from a weakness in some areas of learning. Also, the importance of the teacher's role in understanding dyslexia in order to provide beneficial strategies for affected students will be covered in more detail. Everatt and Reid (2009), indicates that there has been significant progress in research into dyslexia in 
the past twenty years, but so far there is still no clear definition that is universally accepted of what exactly dyslexia is. However, the word dyslexia contains two different parts: (dys) which means difficult or not, and (lexia) meaning reading, words or language. Thus, quite literally, the potential meaning of the word 'dyslexia' is 'difficulty with words' (Catts \& Kamhi, 2005). According to Lyon, Shaywitz, and Shaywitz, (2003), dyslexia is a specific learning difficulty that is neurological in origin and affects the students' ability to process language. This may include accuracy and fluency with word recognition, word decoding and poor spelling. Typically, these difficulties resulted from a deficit in the phonological component of language, which is usually unexpected in relation to the provision of effective classroom instruction and the cognitive abilities, more detailed coverage in the next section. Secondary consequences might include issues in reduced reading experience and reading comprehension in general that might impede the students' progress in background knowledge and growth of vocabulary (Lyon, Shaywitz, \& Shaywitz, 2003).

Voeller (2004) indicated that, at an anatomic level, the brains of students with dyslexia are structurally atypical. Under the microscope, minor anomalies and an increase in ectopic neurons can be seen, as well as sulcal patterns and anomalous gyral in 4-7 persons with dyslexia. The most important are the functional neuroimaging studies, which have detected the special pattern of activation that emerges when a person with dyslexia is reading. Students with dyslexia are not different from other readers when dealing with visuospatial tasks, but as the phonological processing demands increase in the task they may not display the correlated and systematic increase in activity in visual temporal cortex and parietal association cortex that other readers display (Voeller, 2004).

\section{7}


Reid (2011) describes dyslexia as a weakness in short-term verbal memory, which often can be noted in written language as well as spoken language. To provide the most suitable learning environment, teachers should make educational adjustments. Teachers ought to bear in mind that acquiring a in depth knowledge about learners with dyslexia is one of the most important factors and may often play an essential role in a student's overall success in the classroom. Therefore, in order to provide effective teaching strategies for students with dyslexia, teachers should understand the definition and characteristics of dyslexia, as well as the aetiology of this kind of learning difficulty. More detail on the origins of dyslexia is provided in the following section.

\section{The Origins of Dyslexia}

Creating an understanding of the etiological origins of dyslexia has been a topic of interest for researchers and theorists from diverse disciplines that cover reading, such as behavioural, genetics and cognitive neuroscience (Hoskyn, 2008). This section will explain the most important elements of etiology of dyslexia agreed on in previous studies, beginning with biological factors and proceeding to cognitive processes, processing speed and visual processing difficulties.

\section{Biological Factors}

A neurological difference often can cause late or abnormal development of literacy skills and the brains of students with dyslexia appear less ordered and are wired differently to other students. Compared to the average students, information processing is organised differently in individuals with dyslexia (Taub, 2011). In addition, brain scans have shown 
that various areas of the brain are activated. A research studies indicate a high level in a genetic susceptibility to dyslexia as a result of several chromosomes, which is playing a role in the abnormal development of information processing. More specifically, an example of the disorder of phonological processing particularly in language and the auditory processing disorder in perceptual processes that may be as a result of genetic variation (Reid, 2011).

According to phonological theory, which postulates that students with dyslexia often have a specific impairment in the storage, retrieval of speech and representation sounds that may explain their reading pattern and progress. However, even though a number of theorists have different perspectives about the nature of the phonological problems, they do agree on the causal role and central phonology in dyslexia. At the neurological level, it is often assumed that the disorder origin is a congenital dysfunction of the perisylvian brain areas in particular in the left-hemisphere, which might effect the underlying phonological representations, orthographic representations and connecting between phonological. Additionally, the phonological theory is supported by the evidence that students with dyslexia perform poorly on tasks, which required phonological awareness (Franck, Stuart, R., C, D. S., L, D. B., M, C. J, Sarah \& Uta, 2003). Conversely, the weakness of this theory is its inability to interpret the occurrence of motor and sensory disorders in individuals with dyslexia. According to Franck, Stuart, R., C, D. S., L, D. B., M, C. J, Sarah and Uta (2003), the supporters of the phonological theory often may dismiss these kinds of disorders as not part of the main features of dyslexia. For example, they believe their cooccurrence with the phonological deficit as potential signs of dyslexia, but do not consider them as a causal role in the aetiology of reading impairment. 


\section{Cognitive Processes}

Cognitive processes are usually grown by biological characteristics. In the case of students with dyslexia, the mode of attention, functioning, memory, perception, language and thinking is different from that of the majority, developing and improving these is most important during students hood. Often, it is typical that the attention of students with dyslexia is easily diverted because they pay attention, not just to the problem at hand but to everything. Thus, they observe a lot of things and gather a lot of information but often not the ones that they need to concentrate on in that moment. In addition, dyslexia might be accompanied by an attention deficit, which can lead to more serious issues. In the case of attention deficit, spelling mistakes are random, whereas the spelling errors of students with dyslexia often consist of syllable reversal, letter segmentation and writing expressions in more than one word (Reid, 2011). In addition, according to the auditory processing theory, which arose from evidence that students with dyslexia showed poor performance on various auditory tasks, temporal order judgement, including frequency discrimination and abnormal neurophysiological responses to various auditory stimuli, the auditory deficit may be one of the causes in the course of development and the difficulty in reading development (Franck, Stuart, R., C, D. S., L, D. B., M, C. J, Sarah \& Uta, 2003).

\section{Processing Speed}

Breznitz's processing speed study (2008), indicates that the role of the Asynchrony Phenomenon as a means of describing dyslexia. Which is may indicate that dyslexia is caused by a speed of processing gap between and within the different entities taking part in the word decoding process, which is relies on the transfer the information between brain hemispheres. 
This study consisted of different age groups of students with dyslexia and regular readers, from fourth to fifth grade students and adult university students. The research examined the peed of processing among the brain entities using behavioural measures and found that students with dyslexia from all ages were significantly slower than the other readers.

\section{Visual Processing Difficulties}

According to McAnally, Castles and Stuart (2000), most early research was directed at sensory processes in vision; the evidence for a defect in visual processing in dyslexia has been more robust. Students with dyslexia often have a deficit in the magnocellular channel in the visual system, which is responsible for fast temporal-visual processing. The visual processing defect refers to a reduced ability to create a sense of information taken through the eyes. This varies from problems involving sharpness of sight and visual processing difficulties that often affect how visual information is processed or interpreted. This defect may affect reading generally, especially when students with dyslexia are dealing with large amounts of text. Although there seems to be a strong association between the difficulties of visual processing and dyslexia, that does not mean all students with dyslexia are highly susceptible to visual processing deficit. In fact, not all students who suffer from visual processing difficulties will necessarily exhibit the characteristics of dyslexia (Georgiou, Papadopoulos, Zarouna \& Parrila, 2012).

As mentioned above, the Raid study (2011) found that there is a high level of genetic susceptibility resulting from several chromosomes in the context of dyslexia. Breznitz (2008) studied students in fifth and sixth 
grades in primary schools and found that processing speed was an aetiology of dyslexia. It is still difficult to determine the major causes of dyslexia because research in this area is still continuing. Therefore, teachers should learn ongoing about the latest studies in the field of dyslexia as there are always new studies being done. It is considered that both students with dyslexia and their teachers face a number of difficulties and obstacles in the classrooms, which can impede the progress and the success of the learning process. This will be the subject of the next section, which discusses core difficulties related to dyslexia.

\section{Eore Difficulties Related to Dyslexia}

Providing effective teaching strategies to support students with dyslexia in primary schools, requires teachers at first to be more knowledgeable of the signs that indicate dyslexia and the difficulties facing these students in order to apply teaching strategies that are commensurate with their particular needs (Farrell, 2012). Furthermore, these signs or difficulties may appear in the classroom, so teachers should try to minimize them. Examples of these difficulties are a lack of interest in studying, difficulty in dealing with numbers and text, and backward writing (some students with dyslexia can be prone to writing numbers and spelling words backwards). In addition, these students can get confused between left and right directions, skills that are often used in maths, and thus face difficulties in solving numerical problems (Montgomery, 2007). Teachers are often the first to notice the signs of dyslexia in students, however sometimes it is easy for teachers to overlook these indicators. According to Lawrence (2009), one reason for this omission might be that not all students with dyslexia show clear signs of it. 
Despite this, there are studies confirming that students with dyslexia can succeed, make significant progress and overcome this difficulty. An interesting study by Balido-Dean (2010), conducted mostly in Texas, USA, investigated third, fourth and fifth grade students with dyslexia to find out whether or not there was a significant difference in the success rates of students with dyslexia in 2007-2008 compared to 2008-2009 and to 20092010. The study was limited to six schools, four elementary schools and two intermediate schools, which were implementing a dyslexia program. This dyslexia program was designed to utilise all of the brain's learning pathways to enhance learning and memory, focusing on phonemic awareness, components of linguistic patterns, language processes and structure, and graph phonemic knowledge. The results showed that the dyslexia program appeared to be working for students with dyslexia at the third, fourth and fifth grade levels, and these students seemed to be progressing, which clearly confirmed that it is not difficult for teachers and other responsible parties such as parents to treat dyslexia. The study also confirmed the importance and effectiveness of the establishment of programs and strategies to help students with dyslexia during their learning. There are a lot of students with dyslexia who are doing fairly well with the implementation of new techniques and strategies of teaching. It is important for successful teachers to identify and distinguish the characteristics and behaviours of students with dyslexia from other learning development issues that can be seen in the primary school classroom context, so that they can apply appropriate teaching strategies to support students with dyslexia. In addition, the teacher should always be optimistic and build new strategies for these students. Studies discussing effective strategies for students with dyslexia are presented in depth in the following section. 


\section{Current Evidence for Teaching Strategies to Support Students with Dyslexia}

There are numerous strategies that can be employed for students with dyslexia, and teachers should always take into account that not all students with dyslexia will respond to the same strategies. It is essential for teachers to find out what will work with each student (Pollitt, Pollock \& Waller, 2004). This section is designed to cover a number of strategies that could benefit teachers in addressing some of the difficulties for students with dyslexia in primary schools. Students with dyslexia in the primary schools context need special teaching strategies in order to improve their learning because it is a critical learning development time for students. Without appropriate support and teaching, students with dyslexia will have increasing difficulty accessing the curriculum and become more aware of their suboptimal performance in their reading, writing and spelling performance, compared to their classroom peers(Sónia, 2012). Moreover, less access to the written materials can affect them in terms of enrichment, ideas, skill practise, information gathering, and also sheer enjoyment of books (Riddick, Wolfe \& Lumsdon, 2012). The Revised Code of Practice (2001) emphasises that in the primary school years it is essential that students progress at a steady rate to acquire the skills that they will need in their adult life. Furthermore, the role of the skilled teacher is important to ensure progress is well maintained at an individual's level (Riddick, Wolfe \& Lumsdon, 2002). Thus, supporting students with dyslexia in order to help them improve their learning often requires teachers to create special strategies to facilitate their students' learning process. A number of strategies can be arranged according to their importance and application effectiveness: assessment strategy, multisensory teaching strategy, reading strategy, numeracy strategy and dyslexiafriendly classroom strategy, which are now discussed. 


\section{Assessment}

work is helpful for undertaking basic, For example, teachers can consider the students's view when looking at different activities and what they enjoy or do not enjoy in the classroom. This might be achieved through asking them about what they find difficult and why they think it is difficult (Riddick, Wolfe \& Lumsdon, 2002). The example of one student, Kylie, 9 years old (Figure 1) shows the importance and effectiveness of this strategy when she expressed her feelings about writing as a result of a the teacher's question.

'I hate it, really hate it; I'd do anything else rather than that [writing]. I'm always last doing the boring stuff so I never get to do anything interesting; like the children that finish early, they can do interesting things. I never get to do that'.

(Kylie, 9 years)

\section{Figure 1 Dyslexia example}

(Riddick, Wolfe \& Lumsdon, 2002, p. 45).

Typically, students have quite specific views about the types of support from which they benefit most and how it feels like when they read and when they have difficulty. This information can help the teacher to avoid difficult situations arising in class, such as asking the students to read out aloud in front of peers, a situation most students with dyslexia find extremely embarrassing (Riddick, et al., 2002).

\section{Multi - sensory Teaching Strategy}

This strategy, involves activating two or more senses through the learning process. For example, the teacher can introduce a lot of hands-on activities such as, the uses of oranges to teach fractions, adding other sensory elements such as sight, touch, smell and taste to an otherwise difficult lesson (Pagliano, 2012). The International Dyslexia Association (2001) points out 
that multisensory teaching is an efficient approach to teaching students with dyslexia. In traditional teaching, students often use two senses: hearing and sight, they see words while reading and they hear the teacher speaking. But many students with dyslexia might have issues in terms of auditory information and visual processing. Therefore, including more of the senses can help these students and make the lesson more interesting by incorporating touch, taste and smell into the lesson. Teachers can implement multi-sensory techniques in multiple ways. Such as, pronouncing a letter noun while looking at that letter on a flash card and ask the students with dyslexia to drawing the letter in the air with his finger. Another technique, the use of clay and dough to make words and letters while looking and saying the word. Also, teacher can bring a sandpaper letter shapes that can allow these students to feel the shape with their finger and saying that letter name and sound. Simply, using multisensory techniques can be by present each idea visually, auditory and tactilely or kinaesthetically (Pagliano, 2012).

\section{Reading}

Reading difficulties can cause many problems for students with dyslexia. John's example may clarify some of these problems that these students can face (Figure 2).

John, now a very successful businessman, remembers his early years at school.

'I used to look at the other kids. They just knew those words. I used to think to myself 'How do they do that?' I'd pick up the book and look at all those letters - they just didn't make any sense to me - just black letters all over the page. My mother and my teachers worked and worked with me, and sometimes I could just sense their frustration. I had one teacher who used to tap her pencil while she waited for me to read the next word - guess she hated my reading session as much as I did!'

Figure 2 Dyslexia example

Figure 2 (Hannell, 2013, p. 14). 
Pollitt, Pollock and Waller (2004) mentioned how students with dyslexia can have the problem of reading fluency. Using reading strategies can help in solving this problem. For example, the teacher can select reading books that contain a large number of familiar words and are more recommended. If these books are a series (that is, follow on from each other), they often have similar core vocabulary, font type and style, and the introduction of the new words is controlled - all of which help students with dyslexia cope (Hannell, 2013).

\section{Numeracy}

Students with dyslexia may have difficulty in numeracy and maths language. Teachers can address this difficulty through encouraging students to 'talk' about maths, which promotes students sharing ideas, and encourage them to translate maths into a story. For example, $3+2=5$ can be translated as 'Mum bought three apples, then two more, so altogether she had five apples' (Henderson, 2012, p. 44). Teachers can also use the classroom ceiling and walls, placing charts of important numbers to help make numeracy more likable for students with dyslexia (Politt, Pollock \& Waller, 2004).

\section{Dyslexia - Friendly Classroom}

This strategy is based on creating a more positive and energetic environment in the classroom, for example having a fully organised class environment with clear instructions to minimise noise, and mixing visual and auditory activities within each lesson. Also, students with dyslexia in friendly classrooms should sit within easy eye contact of the teacher, and the teacher should provide thinking and talking time. All of these can help teachers in creating a friendly classroom and help LD students to learn in a better environment (Pavey, 2007). 
Above all, in order to provide the most suitable strategies, teachers need to have a wide understanding of the problems that students with dyslexia might have within the classroom situation. In addition, teachers need to be more flexible in their own strategies so that they can find a strategy that suits their students with dyslexia, rather than expecting that all students will learn in one way (Farrell, 2012). This section has sought to provide teachers with some interesting strategies that can be employed. The following section moves on to discuss the other learning difficulty that is a focus of this report - dyscalculia and its current understanding.

\section{Current Understandings of Dyscalculia}

Dyscalculia is a specific learning difficulty that often becomes visible for primary school teachers when students start to struggle in maths. Most primary classrooms have an equal number of children struggling with mathematics, and teachers need to understand this difficulty to provide students with dyscalculia with better learning quality (Hannell, 2013).

This section will review definitions of dyscalculia and focus on challenges that face students with dyscalculia, and the teacher's role in understanding this difficulty to provide suitable strategies for these students. Generally, humans are born with particular numerical skills and an axiomatic understanding of numbers. These skills allow students to distinguish between large numbers of objects, sounds and action (Kyttälä, Aunio\& Hautamäki, 2010). Early numeracy, which is the students' ability to deal and understand quantities, is thought to be important for learning mathematics in school years (Geary, 2007; Jordan, Kaplan, Locuniak \& Ramineni, 2007). Mathematics is defined as a symbolic language that involves numbers, chance, algorithm, form and change (Van De Walle, 
2004). The difficulty with the complexities of numerical processing skills is called 'dyscalculia' (Landerl, Bevan \& Butterworth, 2004). Hannell (2013), states that, the meaning of the word 'dyscalculia' literally is a disorder in calculation skills. Dyscalculia can be defined as a specific learning difficulty, which is represented in impairments in learning arithmetic facts, performing accurate and fluent calculations and processing numerical magnitude (Wilson\& Swanson, 2001).

Students with dyscalculia often face issues to obtain the essential concepts that underpin skills in performing mathematical steps (Hannell, 2013). Whilst students with dyscalculia struggle to learn mathematics and have difficulty in terms of an intuitive grasp of numbers, it is most likely that they are not unintelligent and may succeed in non-mathematical subjects. A student who struggles in a maths lesson more often starts to develop a fear of maths, which may lead to a loss of self-esteem and anxiety. In addition, it is thought that dyscalculia might be as result of a variation in brain function. Another study argues how students with dyscalculia can also have other LDs, such as dyslexia. This is supported by Soares and Patel (2015), who indicate evidence of between $17 \%$ and $70 \%$ of students with dyscalculia also having reading problems. In addition, between $11 \%$ and $56 \%$ of students with dyslexia also suffer from dyscalculia, since those with dyslexia may have added difficulties. For example, it is suggested that children with dyslexia can be confounded in maths tests containing word problems (Soares \& Patel, 2015). Dyslexia difficulties including numeracy issues were mentioned in the previous section of this report, together with recommended strategies for this particular issue. 
Students with dyscalculia tend to be less accurate in multiplication and single-digit subtraction than controls and are often significantly slower in addition, too. Also, students with dyscalculia can have problems with facts, general knowledge and knowledge of arithmetical procedures (Soares $\&$ Patel, 2015). The teacher's responsibility to students with dyscalculia is an important one because it can help in reducing their difficulty. If the teacher fails to help these students, their frustration and fear of numeracy may increase. Therefore, the importance of teachers' familiarity with and knowledge of dyscalculia can be considered as one of the reasons for providing strategies commensurate with these students in primary schools (Williams, 2013). The following section will cover the origins of dyscalculia to help provide a clearer picture of the dyscalculia difficulty for teachers and other responsible parties.

\section{The Origins of Dyscalculia}

According to Michaelson (2007), although some cognitive sciences have not reached very far in establishing a clear understanding of dyscalculia, there have been some discoveries that have helped in developing a number of important correlations. Once teachers of students with dyscalculia understand the origins of these students' difficulties, they can support them to use the mathematical curriculum more readily. This section will focus on describing the most important etiology of dyscalculia, as discussed in a number of research cases, involving issues related to genetics, difficulties in number sense, working memory issues, and basic number processing and non-numerical deficits. 


\section{Genetics}

There is evidence that mathematical abilities may related to specific heredity, with an analysis of multivariate genetics finding that approximately $30 \%$ of the genetic variance was specific to mathematics (Rohl\& Milton, 2002). In some families, it is more common to find more than one member with dyscalculia, with often a sibling or parent with similar math issues (Butterworth, 2010). This also supports the proposition that dyscalculia may be genetic. Almost $10 \%$ of parents of students with dyscalculia have reported that at least one or two other family members needed assistance with mathematics (Geary \& Hoard, 2001).

\section{Working Memory}

It is a deficit for students with dyscalculia More specifically, 'immediate memory,' that works as short-term memory retention or in longterm memory where information is stored for a period of time and then retrieved (Hannell, 2013). Geary (2004), states that many students in primary years have issues in retrieving basic arithmetic data from long-term memory. In addition, 'working memory' deficits in students with dyscalculia in both the visual spatial domains and verbal contribute to mathematical difficulties (Wilson \& Swanson, 2001). Long-term memory deficits are often very obvious in the students with dyscalculia. For example, usually the Students with dyscalculia carefully counts their fingers to reconstitute the number fact that they failed to store or cannot retrieve from their memory (Riddick, et al., 2002). Additionally, a number of studies agree that a feature of students with dyscalculia might be as a result of difficulty in remembering arithmetic facts and learning (Geary \& Hoard, 2001; Shalev \& Gross-Tsur, 2001; Landerl, Bevan \& Butterworth, 2004). 


\section{Basic Number Processing}

Basic number processing is often seen in students with dyscalculia, where they struggle to show the same understanding of numerical information, such as when judging whether two numbers provided in various formats are identical or not. This suggests that basic number processing might not be activated automatically in students with dyscalculia as it is in their peers (Price \& Ansari, 2013). This is supported by Landerl, Bevan and Butterworth (2004), who studied 31 students aged four, eight and nine and selected form 11 middle schools in London, UK. In particular, students with dyscalculia and other LDs were compared to controls in a variety of basic number processing tasks. The results show that dyscalculia involves difficulty in basic numerical processing.

\section{Non - Numerical Deficits}

This deficit indicates that dyscalculia may lie in disturbances of domain-general cognitive mechanisms, such as visual-spatial processing, working memory or attention. Support of this hypothesis is evidence that students with dyscalculia underperform on tests of different aspects of working memory. The findings indicate a coupling between deficits in arithmetic learning and working memory difficulties. It is believed that working memory is an important cognitive component for the acquisition of numeracy skills, that students with dyscalculia may have problems with working memory (Price \& Ansari, 2013).

It is important for teachers to be aware of the origins behind dyscalculia, but this alone is not enough to provide a successful integrated learning environment for students with dyscalculia; it is also essential that teachers know the difficulties and obstacles faced by these students. The 
next section will present information about the core difficulties related to dyscalculia.

\section{Core Difficulties Related to Dyscalculia}

Teachers' knowledge about the symptoms of dyscalculia can help in reducing difficulties for those with dyscalculia in primary-aged years. There is a range of signs and particular difficulties that students with dyscalculia can experience, creating potential barriers, from emotional and intellectual barriers generally to learning mathematics specifically. Teachers should consider these signs while teaching in order to provide effective teaching strategies for LD students (Chinn, 2012). One of the signs teachers can recognise is when a student exhibits problems with visual-spatial skills, which is a problem in mental manipulation of scenic images. Symmetry, geometry and tessellation might all prove to be real challenges for dyscalculia students. For example, holding and recording a visual image accurately can be difficult (Hannell, 2013). This illustration below (Figure3) shows what can occur when a student with dyscalculia had to copy the number line.

$$
E Q,+P, \text { DP, } \partial P, T P, Q P, P P,, 001
$$

Figure 3 Dyscalculia example

He had to turn the line backwards to record it; this process could easily disturb his sense and ability to type the numbers in the line correctly. 
The student also wrote 39, 49, 59 and 69 instead of 93, 94, 95 and 96 (Hannell, 2013). In addition, some students with dyscalculia experience difficulties grasping the concept of area, volume and perimeter accurately. The following example shows a nine-year-old student (Figure 4), who tried to record the measurement of a table. He tried to use a system of counting how many rulers $(30 \mathrm{~cm}$ ruler) and their lengths from each side.

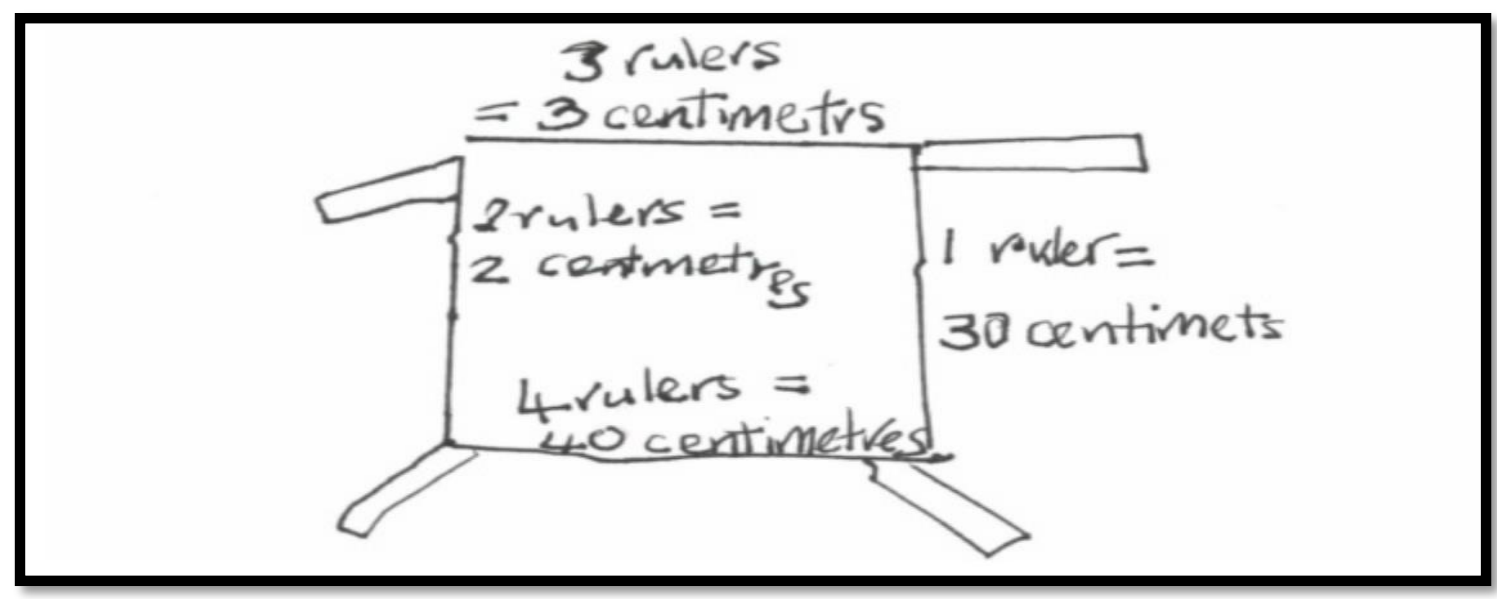

Figure 4 Dyscalculia example

Figure 4.

As can be seen, the student had difficulty in lifting and placing the ruler correctly, ending up with an uneven number of rulers on each side (Hannell, 2013).Dyscalculia difficulties can arise due to many factors, including poor teaching, behavioural attention problems and low socioeconomic status. It is recommended that teachers watch out for their own errors when teaching students with dyscalculia, because sometimes learning difficulties may increase as result of poor teaching. Teachers, too, face issues: a number of teachers have pointed out the difficulty in identifying dyscalculia among many other student issues in the classroom (Williams, 2013). 
Teachers have an important role in helping dyscalculia students, initially by providing effective strategies and a conducive environment. Since the main focus of this report is to outline some of the most suitable strategies for tackling dyscalculia, the next section will discuss the current evidence concerning teaching strategies supporting students with dyscalculia.

\section{Current Evidence of Teaching Strategies to Support Students with Dyscalculia}

The inherent goal in the importance for teachers to understand the characteristics of students with dyscalculia is to inform the development of successful strategies and educational interventions (Shalev \& Gross, 2001). Obviously, teaching strategies for students with dyscalculia should vary with regard to individual weaknesses and strengths. Students who are experiencing in difficulty in mathematics will initially need one-to-one teaching ((Van de Walle, 2004). It is essential for teachers to remember that students with dyscalculia are varied and have their own unique ways of learning, which suggests teachers utilize apparatus and teaching strategies that suit these students' learning styles. Thus, this section is designed to review the most useful strategies for teaching students with dyscalculia in order to provide teachers with some strategies to help them with their teaching. Furthermore, it is vital for the teachers to develop a trustworthy repour with students with dyscalculia in order to be able to talk with them about the aspect of topics that they find difficult or worrying (Van de Walle, 2004). These types of strategies can be helpful for students with dyscalculia at all levels, helping them understand and learn appropriately. Strategies are presented according to their effectiveness, beginning with dealing with anxiety and proceeding with assessment of numeracy, multi-sensory teaching strategies, finger counting, subvocalizing, visualising, and bridging. 


\section{Dealing with Anxiety}

As mentioned above, dealing with anxiety about maths is a concern for students with dyscalculia. Henderson (2012) discusses how Numicon shapes - a multi-sensory, three-dimensional device - can provide structured images of numerals (Figure 5). These shapes can be effectively used in conjunction with other resources that help students with dyscalculia. One way is for the teacher to present coloured shapes to students. This is can give a clear picture of the sequence and value of numbers, and thus students can grasp the relationships between size and numbers. The shapes are easy to hold and fun to use, and so, as a result, the lessons become more enjoyable, which in turn helps to avoid anxiety about maths lessons. Once students with dyscalculia have mastered the shapes, coloured number rods can be used to move them further along with their mathematical thinking (Henderson, 2012).

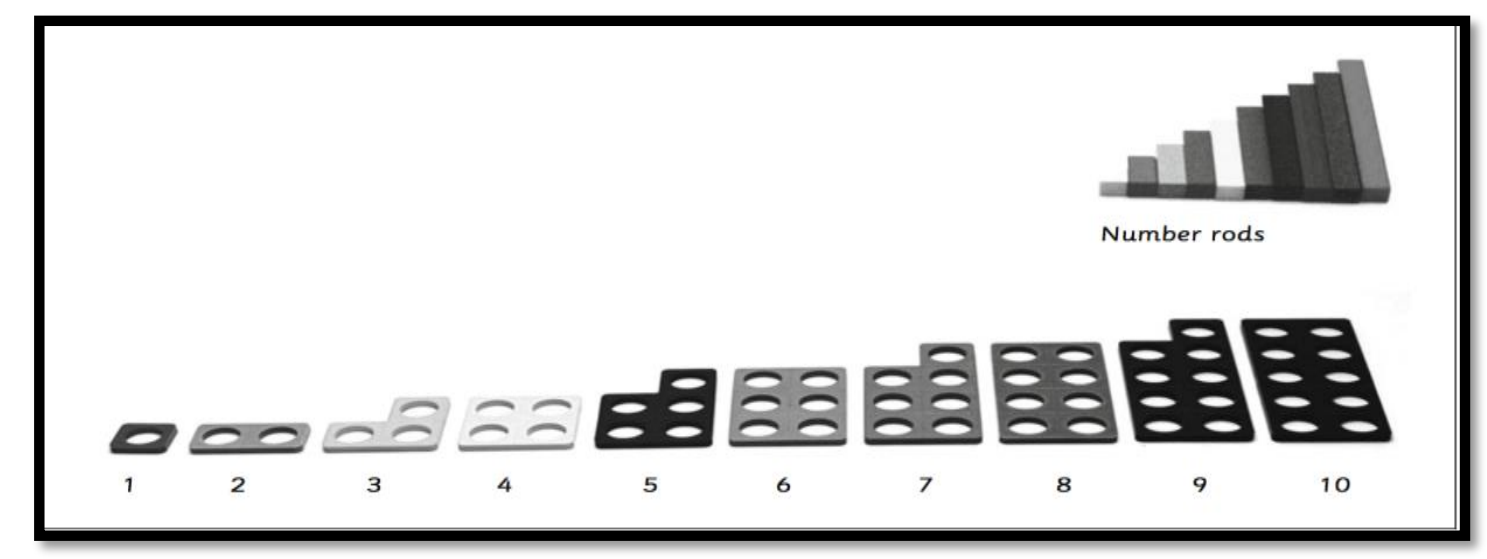

Figure 5 Numicon shapes with numerals.

\section{Assessment of Numeracy}

It is another useful strategy where investigation allows the teacher to identify what the student can do and how they reach their answers, in order to devise a suitable teaching strategy. It is important to make the assessment 
as engaging and exciting as possible, thus the students enjoy the experience more (Emerson\& Babtie, 2010). Students with dyscalculia are likely to have repeated failure in maths and might have a negative attitude in relation to this difficulty. Students with dyscalculia need to be encouraged to be more relaxed and allow them enough time to explain and talk about what they are thinking. It is essential for a teacher to be sensitive to the student's selfconfidence, at all times, while the investigation is running. The key to the success of the assessment is the use of short sentences and simple language to make the instructions clear (Emerson\& Babtie, 2010).

\section{Multi-Sensory Teaching Strategies}

As mentioned in the dyslexia strategies section, this concerns the effectiveness in helping students with LDs such as dyslexia and dyscalculia. This strategy involves using pictures, colours and physical apparatus, using tambourine tapping, singing, music, clapping and movement, for example when a student jumps from one painted numeral to another painted numeral on the floor, in sand or in water. Interactive white boards can be also helpful for teachers in reinforcing calculation games. It is recommended the teacher presents many games and uses repetition for reinforcement (Henderson, 2012). This particular strategy can be useful with using technology to provide interactive programmes, which helps students with dyscalculia to learn. For example, there are special programs that suit the needs of students who struggle in maths, such as applications on iPad and DS for calculation games using addition and subtraction, helping the student learn the solution in the shortest time. They can also be fun (Michaelson, 2007). 


\section{Finger Counting}

It is an essential precursor to learning basic mathematical steps and is a primary tool used by students with dyscalculia to count initially. However, these students need to develop a number of efficient strategies such as visualising the number patterns or partitioning to move forward with more difficult mathematical challenges (Emerson\& Babtie, 2010). Therefore, teachers should observe carefully how students use their fingers, to keep track of the number of numeric groups being added. It is suggested that teacher activate this strategy in teaching those students, especially in related to multiplication skills (Reid \& Lienemann, 2013).

\section{Bridging}

Bridging strategy can be through 10 or a multiple of 10 . Clearly, this is a very helpful calculation strategy for students with dyscalculia. 10 often used as a stepping-stone to gather two single-digit of numbers and the answer will be more than 1 . For example: $5+8=(5+5)+3=10+3=13$. Thus, students need to understand the bonds of 10 to use this strategy successfully (Emerson\& Babtie, 2010). This strategy is supported by Emerson, Babtie and Butterworth (2014), who pointed out its advantages for students with dyscalculia. bridging through 10 is easier to model; it can be adopted to work with large numbers; it is rooted in the base 10 structure; it is used for subtraction calculation, addition and missing addends; and it is a very effective strategy for working with line numbers, which is a problem faced by these students, as mentioned previously.

Students can continuously develop their mathematical skills, although the rate of the development varies considerably. Some students with dyscalculia may learn slowly, regardless of their level of difficulty. 
Students with dyscalculia often vary in their skills, depending on their abilities, so different strategies, books, materials and pedagogical styles should appeal to these students' abilities (Price \& Ansari, 2013). This again confirms the teacher's role in assisting students with dyscalculia. This is can be through teachers understanding the problems and etiology of this particular difficulty and how these students can suffer from it, especially when they have had previous negative experiences of poor teaching. In addition, providing these students with varied conditions, a conducive learning environment and suitable strategies can enable the teaching of students with dyscalculia to be more exciting and rewarding.

This section was written in order to provide teachers in primary schools with suitable strategies for teaching dyscalculia students. The next section will concern the synthesis of dyslexia and dyscalculia.

\section{Synthesis of Dysiexia and Dyscalculia}

A review of the similarities and differences between dyslexia and dyscalculia can help teachers and other responsible parties with how to distinguish between these two difficulties. Dyslexia and dyscalculia are two different types of LDs and each has its etiologies and obstacles that increase the degree of difficulty. According to Landerl, Fussenegger, Moll and Willburger (2009), discussion about the similarities and differences between dyslexia and dyscalculia is an ongoing debate, utilizing research already conducted and new studies that continue to be conducted. As mentioned previously, dyslexia refers to a deficit in the acquisition of reading skills, while dyscalculia is a deficit in the acquisition of mathematical skills. Both of these types of LDs are assumed to be of 
neurobiological origin and have their own various causes that affect the development of literacy or mathematical skills. The percentage of academic failure in dyslexia and dyscalculia vary widely, though, depending on definitional criteria. Prevalence rates of these specific difficulties range from $4 \%$ to $7 \%$, and they frequently co-occur (Landerl et al., 2009). Some specific similarities and differences between dyslexia and dyscalculia will now be discussed in more detail.

\section{Similarities}

Students with both dyslexia and dyscalculia can experience multiple problems. An interesting study by Wiguna, Setyawati, Kaligis and Belfer (2012) was conducted in 27 primary school students with LDs in Jakarta, Indonesia. The aim was to examine LDs with working memory. Working memory is defined as sufficient storage and retrieval systems for remembering words and facts. The result revealed that working memory can easily impact LDs, including both dyslexia and dyscalculia.

Another problem affecting both these groups of sufferers is phonological deficit, for example problems in relation to sequencing sounds, both typing and imitating a polysyllabic word or a series of numbers and with reading them A common issue is distinguishing between numbers such as 6 and 9, 2 and 5, and symbols such as p, d, b, q. It is assumed that dyscalculia may be caused by the phonological verbal deficits that also underlie dyslexia, a problem that can be present when students are confused by similar-sounding words (Hong \& Chick, 2013). Also, students can exhibit a deficit in the processing of numerosity, such as in addition, subtraction and division (Landerl et al., 2009). 


\section{Differences}

Dyscalculia and dyslexia vary greatly in terms of genetic conditions, in spite of a certain overlap. There is no clear evidence that dyscalculia might be associated with phonological deficits, which is often observed in students with dyslexia. Landerl et al.'s study (2009) used four groups of students with dyslexia and dyscalculia, between 8 and 10 years of age, from an urban Austrian school to examine whether dyslexia and dyscalculia are associated with two independent cognitive deficits, phonological deficit and the number module. The results revealed that the higher performance of students in naming speed and phonological awareness was from the developing control group than the group with dyscalculia.

Evidence is not clear on the subject. One study mentioned the similarity between dyslexia and dyscalculia in working memory and another study argued there is no relationship between dyscalculia and phonological deficits. What is clear is that the similarities and differences between dyslexia and dyscalculia can sometimes be confusing for the teacher to recognise, but ongoing familiarity with students and reading the latest articles could help. The following section will present this study's recommendations.

\section{Recommendations}

A large number of educational strategies are available for teachers to build on the strengths of students with LDs such as dyslexia and dyscalculia in primary schools. Deciding which specific teaching strategy is right for these students can be hard for teachers. The aim of this research paper, therefore, is to provide teachers with some useful strategies for teaching students with dyslexia and dyscalculia in order to create a productive 
environment. There are some recommendations that can be made to benefit teachers and students with dyslexia and dyscalculia in their education.

- Teachers should continually increase their knowledge and be more cognizant of new studies, books, therapies, programs, and educational techniques.

- Teachers are encouraged to learn about the differences between these specific learning difficulties.

- A guidebook for the teacher is highly recommended.

- According to Farrell (2012), it is useful for the teacher to review the student's evaluation records history, if possible, to help identify specifically where the student has difficulty.

- To emphasise the strengths of students with dyslexia and dyscalculia, it is recommended that teachers constantly provide positive feedback and many opportunities for practice (Bousch, Pederson, Espin \& Weissenburger, 2001).

- Teachers of students with dyslexia should limit reading demands, provide a subject word list and keep students on task with an interesting article.

- Teachers should provide individual support for these LD students, such as increased reading and problem-solving time. Those strategies discussed above, in the teaching strategies to support students with dyslexia section, are highly recommended.

- Students with dyscalculia are often very aware of their weakness at maths compared with their peers (Chinn, 2012). Teachers can help them to create a positive mathematics lesson by allowing them extra time and by activating strategies commensurate with their abilities, 
such as those mentioned above in the teaching strategies to support students with dyscalculia section.

Finally, teachers of students with both dyslexia and dyscalculia should always believe that a strategy that may suit one student might not do so for other students, since each strategy is dependent on the capabilities of each student. Thus, it is highly preferable for the teacher to be patient and optimistic about the effectiveness of teaching strategies. Students with dyslexia and dyscalculia just need to be understood by their teachers, parents and others responsible in order to achieve more and succeed in their education. The next, and final, section will be the conclusion of this research paper.

\section{Eonclusion}

Students in primary schools that include students with LDs such as dyslexia and dyscalculia are as much the children who will contribute to the development of the world's future as any other. They have the right to support and help; they have different abilities to other students, and their abilities need to be understood. Students with dyslexia and dyscalculia in primary years often suffer from low self-esteem and consequently cover up their difficulties. Therefore, it is essential for teachers to identify LDs early and help these students to build resilience from the setbacks and problems they often face. Teachers need to consider that students with dyslexia and dyscalculia have many talents and skills. Their abilities should not be measured purely on the basis of their difficulties; Reid and Lienemann (2013) point out that is highly likely that students with LDs may actually have difficulty in just one skill, such as literacy skills for students with 
dyslexia. The aim of this research paper was to provide teachers with the most recommended strategies from numerous studies. The effectiveness of these strategies might be high if teachers consider that success for students with dyslexia and dyscalculia requires a focus on individual progress, individual achievement, individual learning and collective education organised by the teacher (Clarke, Embury, Jones, \& Yssel, 2014). A successful teacher is the one who develops him- or herself through reading the latest books, articles and studies in the field of education with LDs in order to provide LD students with suitable strategies. The importance of teachers setting students' attitudes, characteristics and behaviour can help lead students with dyslexia and dyscalculia to successful life outcomes. Finally, students with dyslexia and dyscalculia, like all students, can thrive on challenges and success. 


\section{References}

Balido-Dean, L. (2010). Dyslexia: An analysis of dyslexic students at the elementary level. Retrieved from http://search.proquest.com/docview/902033275?accountid=13380

Barber, C. (2011). Understanding learning disabilities: An introduction. British Journal of Healthcare Assistants, 5(4), 168-169. doi:10.12968/bjha.2011.5.4.168

Bousch, T. W., Pederson, K., Espin, C. A., \& Weissenburger, J. W. (2001). Teaching students with learning disabilities: Perceptions of a firstyear teacher. The Journal of Special Education, 35(2), 92-99. doi:10.1177/002246690103500204

Breznitz, Z. (2008). The Origin of Dyslexia: The Asynchrony Phenomenon. In G. Reid, A. Fawcett, F. Manis, \& L. Siegel (Eds.), The SAGE Handbook of Dyslexia (pp. 11-30). London: SAGE Publications Ltd. http://dx.doi.org/10.4135/9780857020987.n2

Burgstahler, S., \& Moore, E. (2009). Making students services welcoming and accessible through accommodations and universal design. Journal of Postsecondary Education and Disability, 21(3), 155-174.

Butterworth, B. (2010). "Foundational numerical capacities and the origins of dyscalculia". Trends in Cognitive Sciences, 14(12), 534-541. doi:10.1016/j.tics.2010.09.007. PMID 20971676.

Bowe, F. (2005). Making inclusion work. Upper Saddle River, NJ: Merrill Education/Prentice Hall.

Catts, H.W., \& Kamhi, A.G. (2005). Language and reading disabilities (2nd ed.). Boston: Pearson. 
Chinn, S. J. (2012). More trouble with maths: A complete guide to identifying and diagnosing mathematical difficulties. Abingdon, Oxon; New York, N.Y: Routledge.

Clarke, L. S., Embury, D. C., Jones, R., \& Yssel, N. (2014). Supporting students with disabilities during school crises: A teacher's guide. TEACHING Exceptional Children, 46(6), 169. doi: 10.1177/ 0014402914534616

Cortiella, C., \& Horowitz, S. H. (2014). The State of Learning Disabilities: Facts, Trends and Emerging Issues. New York: National Center for Learning Disabilities.

Emerson, J., \& Babtie, P. (2010). Dyscalculia assessment Continuum International Publishing Group.

Emerson, J., Babtie, P., \& Butterworth, B. (2014). The dyscalculia solution: Teaching number sense. London: Bloomsbury Educational.

Everatt, J. and Reid, G. (2009) An overview of recent research. In: G. Reid (ed.), The Routledge Dyslexia Companion. London, Routledge.

Farrell, M. (2012). The effective teacher's guide to dyslexia and other learning difficulties (learning disabilities): Practical strategies (2nd ed.). New York, NY: Routledge.

Franck, R., Stuart, R., C, D. S., L, D. B., M, C. J., Sarah, W., \& Uta, F. (2003). Theories of developmental dyslexia: Insights from a multiple case study of dyslexic adults. Brain,126 (pt. 4), 841-865. doi: 10.1093/brain/awg076

Geary, D. C. (2004). Mathematics and learning disabilities. Journal of Learning Disabilities, 37: 4-15.

Georgiou, G. K., Papadopoulos, T. C., Zarouna, E., \& Parrila, R. (2012). Are auditory and visual processing deficits related to developmental dyslexia? Dyslexia, 18(2), 110-129. doi:10.1002/dys.1439 
Geary, D. C. (2007). An evolutionary perspective on learning disability in mathematics. Developmental Neuropsychology, 32, 471-519.

Geary, D. C. \& Hoard, M. K. (2001). Numerical and arithmetical deficits in learning-disabled students: Relation to dyscalculia and dyslexia. Aphasiology, 15(7), 635-647.

Hannell, G. (2013). Dyslexia: Action plans for successful learning (1st ed.). GB: Routledge Ltd. doi:10.4324/9780203825679

Hannell, G. (2013). Dyscalculia: Action plans for successful learning in mathematics (2nd ed.). Abingdon, Oxon; New York, N.Y;: Routledge.

Henderson, A. (2012). Dyslexia, dyscalculia and mathematics: A practical guide (2nd ed.). New York; London;: Routledge.

Hoskyn, M. (2008). Neurobiological and experiential origins of dyslexia: An introduction. Developmental Neuropsychology, 33(6), 659-662. doi:10.1080/87565640802418563

Hong, B. S. S., \& Chick, K. A. (2013). Understanding students with learning difficulties: How do they learn? Kappa Delta Pi Record, 49(1), 30.

International Dyslexia Association. (2001). Just the facts: Information provided by the International Dyslexia Association: OrtonGillingham-Based and/or Multisensory Structured Language approaches. (Fact Sheet No.968). Baltimore: Maryland.

Jordan, N. C., Kaplan, D., Locuniak, M. N. \& Ramineni, C. (2007). Predicting first-grade math achievement from developmental number sense trajectories. Learning Disabilities Research \& Practice, 22, 36-46. 
Kyttälä, M., Aunio, P., \& Hautamäki, J. (2010). Working memory resources in young students with mathematical difficulties. Scandinavian Journal of Psychology, 51 (1), 1-15. doi: 10.1111/j. 1467-9450. 2009. 00736.x

Landerl, K., Bevan, A., \& Butterworth, B. (2004). Developmental dyscalculia and basic numerical capacities: A study of 8-9-year-old students. Cognition,93(2), 99-125. doi:10.1016/j.cognition.2003.11.004

Landerl, K., Fussenegger, B., Moll, K., \& Willburger, E. (2009). Dyslexia and dyscalculia: Two learning disorders with different cognitive profiles. Journal of Experimental Child Psychology, 103(3), 309324. doi:10.1016/j.jecp.2009.03.006

Lawrence, D. (2009). Understanding Dyslexia : A Guide for Teachers and Parents. Retrieved from http://www.eblib.com

Lyon, G.R., Shaywitz, S.E., \& Shaywitz, B.A. (2003). Defining dyslexia, comorbidity, teachers' knowledge of language and reading. Annals of Dyslexia, 53, 1-14.

Mackie, K. M. (2007). Learning disabilities severity, classroom setting, and academic performance in middle school. Retrieved from http://search.proquest.com/docview/304764091 ?accountid=13380

McAnally, K. I., Castles, A., \& Stuart, G. W. (2000). Visual and auditory processing impairments in subtypes of developmental dyslexia: A discussion. Journal of Developmental and Physical Disabilities, 12(2), 145-156. doi:10.1023/A:1009459622805

McGuyer, K. (2011). Primary teachers' perspectives on teaching reading to students with dyslexia in the general education classroom

Michaelson, M. T. (2007). An overview of dyscalculia: Methods for ascertaining and accommodating dyscalculic children in the classroom. Australian Mathematics Teacher, the, 63(3), 17-22. 
Montgomery, D. (2007).Spelling, handwriting and dyslexia: Overcoming barriers to learning (1st ed.). GB: Routledge Ltd. doi:10.4324/ 9780203967713

National Center for Learning Disabilities. (2011). The state of learning disabilities: Facts, trends, and indicators. New York: Author. Retrieved from http://www.ncld.org/stateofld

Pagliano, P. J. (2012). The multisensory handbook: A guide for students and adults with sensory learning disabilities. Abingdon, Oxon;New York, N.Y;: Routledge.

Pavey, B. (2007). The dyslexia-friendly primary school: A practical guide for teachers. Thousand Oaks, CA, London: PCP.

Politt, R., Pollock, J., \& Waller, E. (2004). Day-to-day dyslexia in the classroom (2nd ed.). GB: Routledge Falmer. doi:10.4324/ 9780203461891

Price, G. R., \& Ansari, D. (2013). Dyscalculia: Characteristics, causes, and treatments. Numeracy, 6(1), 2.

Rea, P. J., McLaughlin, V. L., \& Walther-Thomas, C. (2002). Outcomes for students with learning disabilities in inclusive and pullout programs. Exceptional Children, 68(2), 203-222.

Reid, G. (2011). dyslexia (3rd ed.). London: Continuum. Retrieved from http://www.eblib.com

Reid, R., \& Lienemann, T. O. (2013). Strategy instruction for students with learning disabilities (2nd ed.). New York, NY: Guilford Press

Riddick, B., Wolfe, J., \& Lumsdon, D. (2002). Dyslexia: A practical guide for teachers and parents. GB: David Fulton Publishers. doi: 10.4324/ 9780203065464 
Riddick, B., Wolfe, J., \& Lumsdon, D. (2012). Dyslexia: A practical guide for teachers and parents. GB: David Fulton Publishers. doi:10.4324/9780203065464

Rohl, M., \& Milton, M. (2002). What's happening in schools for primary students with learning difficulties in literacy and numeracy? A national survey. Australian Journal of Language and Literacy, 25 (1), 25-48.

Samuelsson, S. \& Lundberg, I. (2003). The impact of environmental factors on components of reading and dyslexia. Annals of Dyslexia, 53, 201-217.

Shalev, R. S., \& Gross-Tsur, V. (2001). Developmental dyscalculia. Review article. Pediatric Neurology, 24, 337-342.

Silver, L. B., \& Silver, D. L. (2010). Guide to learning disabilities for primary care: How to screen, identify, manage and advocate for children with learning disabilities. Elk Grove Village, IL: American Academy of Pediatrics.

Soares, N., \& Patel, D. R. (2015). Dyscalculia. International Journal of Child and Adolescent Health, 8(1), 15.

Sónia, L. (2012). Dyslexia through the eyes of primary school teachers.Procedia - Social and Behavioral Sciences, 69, 41-46. doi:10.1016/j.sbspro.2012.11.381

Taub, Marc B,O.D., M.S. (2011). DYSLEXIA. Journal of Behavioral Optometry, 22(2), 48-49. Retrieved from http://search.proquest.com/docview/871723004?accountid=13380

Van de Walle, J.A. (2004). Elementary and middle school mathematics: Teaching developmentally. (5th ed.). New York: Pearson Education. 
Voeller, K. K. S. (2004). Dyslexia. Journal of Child Neurology, 19(10), 740-744.

Von Aster, M. G., \& Shalev, R. S. (2007). Number development and developmental dyscalculia. Developmental Medicine and Child Neurology, 49(11), 868-873. doi:10.1111/j.1469-8749.2007.00868

Wilson, K. M. and Swanson, H. L. (2001), 'Are mathematics disabilities due to a domain-general or a domain-specific working memory deficit?' Journal of Learning Disabilities, 34: 237-48.

Westwood, P. (2004). Learning and learning difficulties: Approaches to teaching and assessment (1st ed.). GB: Routledge Ltd.

Westwood, P. (2008). Teaching students with learning difficulties. (pp. 5570). Camberwell, Vic: ACER Press.

Wiguna, T., Setyawati Wr, N., Kaligis, F., \& Belfer, M. L. (2012). Learning difficulties and working memory deficits among primary school students in Jakarta, Indonesia. Clinical Psychopharmacology and Neuroscience, 10 (2), 105-109. doi:10.9758/cpn.2012.10.2.105

Williams, A. (2013). A teacher's perspective of dyscalculia: Who counts? An interdisciplinary overview. Australian Journal of Learning Difficulties, 18 (1), 1.

Wong, B. Y. L., \& Butler, D. L. (2012). Learning about learning disabilities (4th ed.). US: Academic Press. 